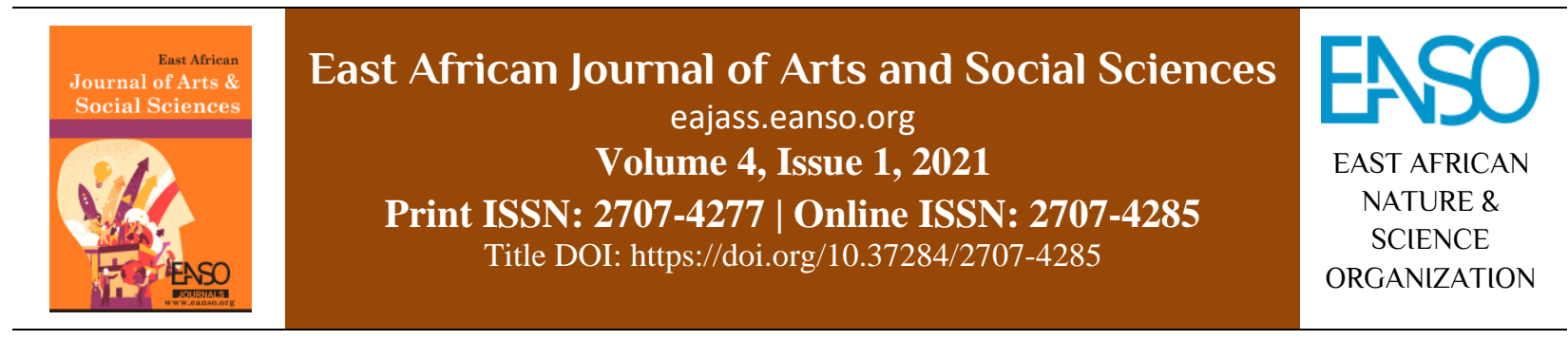

Original Article

\title{
Influence of Women in Leadership in the African Society: A Case of Women Characters in Selected Kiswahili Plays.
}

\author{
Martha Nyangweso Syekei ${ }^{1 *} \&$ Fridah Gesare Oiko ${ }^{1}$ \\ ${ }^{1}$ Rongo University, PO Box 103 - 40404, Rongo, Kenya. \\ *Correspondence email: ondimumartha@yahoo.com.
}

Article DOI: https://doi.org/10.37284/eajass.4.1.450

\section{Date Published: ABSTRACT}

27 October 2021 Research suggests that women in leadership positions pose different and extra challenges as compared to their male counterparts. Yet, the number of women

Keywords: leaders has grown but they are still a small group that is appreciated. This has made the list of their numbers be still relatively low. Leadership studies have focused on

Female, the upbringing and traits of a leader, decision making, psychology of leaders, and

Woman so on but less work has been devoted on the influence of women in leadership in

Character, the African society as portrayed in written literature. Literature is the greatest asset in any society this century. There is a rich literature base on women in leadership.

Gender Equality, Surprisingly little research has been devoted to their portfolio influence. Due to this

Issues, insufficient attention, this study has built profiles of four selected women leaders in

Leadership Kiswahili plays. It has paid attention to the uniqueness of women leaders and

Portfolio. analysed their role and how they are challenged as officeholders on account of their sex. The theory of feminism- a look at the African society was used to help achieve its main tenets like gender equality, gender issues, characterisation based on traits, and thematic focus on plays was used to study this objective. The purposive sampling design was relevant because it proved to provide reliable data for the study by homogeneously analysing written Kiswahili plays. The literature texts used contained few relevant cases where in-depth analysis related to the central issue was studied. The study concluded that women leaders have a great role and have made great strides in leadership, especially in changing the negative perception the continent has on them, that they cannot lead while men exist.

39 | This work is licensed under a Creative Commons Attribution 4.0 International License. 
APA CITATION

Syekei, M. N. \& Oiko, F. G. (2021). Influence of Women in Leadership in the African Society: A Case of Women Characters in Selected Kiswahili Plays. East African Journal of Arts and Social Sciences, 4(1), 39-44. https://doi.org/10.37284/eajass.4.1.450

\section{CHICAGO CITATION}

Syekei, Martha Nyangweso \& Fridah Gesare Oiko. 2021. "Influence of Women in Leadership in the African Society: A Case of Women Characters in Selected Kiswahili Plays". East African Journal of Arts and Social Sciences 4 (1), 39-44. https://doi.org/10.37284/eajass.4.1.450.

\section{HARVARD CITATION}

Syekei, M. N. Oiko, F. G. (2021) "Influence of Women in Leadership in the African Society: A Case of Women Characters in Selected Kiswahili Plays”, East African Journal of Arts and Social Sciences, 4(1), pp. 39-44. doi: 10.37284/eajass.4.1.450.

\section{IEEE CITATION}

M. N. Syekei F. G. Oiko. "Influence of Women in Leadership in the African Society: A Case of Women Characters in Selected Kiswahili Plays", EAJASS, vol. 4, no. 1, pp. 39-44, Oct. 2021.

\section{MLA CITATION}

Syekei, Martha Nyangweso \& Fridah Gesare Oiko. "Influence of Women in Leadership in the African Society: A Case of Women Characters in Selected Kiswahili Plays". East African Journal of Arts and Social Sciences, Vol. 4, no. 1, Oct. 2021, pp. 39-44, doi:10.37284/eajass.4.1.450.

\section{INTRODUCTION}

Over time countless women have led nations, kingdoms, counties, and even military groups. They have made tremendous efforts in the rise to be great leaders of our time. Even though laws and constitutions of various countries have advocated for the gender balance in leadership positions across the board, this achievement has not come easily. It has not brought the desired balance and participation. There has been no guarantee of equal access of women to various leadership positions. The glass ceiling has not been achieved yet. There is rich literature based on women in politics. Numerous studies assess challenges facing women in politics, like sexism, raising money, lack of mentoring, and party support or otherwise. There have been relentless efforts to achieve this and this has been clearly portrayed in written Kiswahili plays. The plays display the woman character as up to and making great strides towards achieving what society deems impossible. We found that literature mirrors society and societal values. It displays men as rigid and homogeneous in leadership traits. Among the great values to be emphasised is gender balance (Jackson, 1998). Women leaders have been the exception both in terms of humanity's collective experience with governance and widespread perceptions about leadership, governance, and gender which have always favoured men and have been pervasive across time and cultures.
A study of women characters can be traced back to Ancient Egypt, which dominated the continent for a period of time unparalleled in recorded history. According to Chauveau (1997), queens in ancient Egypt were typically revered as wives of God and these wives of Pharaohs not only had esteem and influence but some governed in the capacity of an official woman or a vice ruler. The impact of Egyptian culture on these female leaders was considerable; such was the case of Ahhotep, Queen of Thebes in the fifteenth century B.C who both ruled and bore three futures.

Egyptian rulers, elsewhere in Sub-Saharan Africa, rulers' spouses as well as queen mothers, often shared a sort of joint rule in previous centuries. The same history of women rulers is found in other continents. Although the practice of Islam in the Middle East has generally oppressed women, history notes the existence of Arabian queens who governed (Jackson, 1998). Similarly, even though women were second-class citizens in ancient China, in Confucian times, concubines and a few women became legitimate rulers. In Europe, women not only ruled but governed nations as Renaissance; Catherine the Great led a life full of accomplishments and she remains one of the longest leaders to reign and widely celebrated in Russia, Europe, and across the world. Oral and written literature tells of the history of women leaders in Asia and the Americas. 
In the traditional African society, children were brought up and educated traditionally. Girls and boys were not taught together because they were expected to play different roles in the community. Girls were taught to take care of the family. They were taught agriculture, domestic work, basketry, and pottery. Boys were taught to behave like adults. They took care of their families and properties such as animals. They were encouraged to be brave and defend the clan in case of war. They were taught to hunt, warfare and carpentry.

The selected literature guides us to understand women in a patriarchal culture. Culture dictated a way of life in each community. It defended the people's needs and their environment. Simone de Beauvoir (1949) in the Second Sex pointedly criticised patriarchal culture and analyses the marginal position of women in society and the arts. She describes a male discourse within which practices occur. Beauvoir posits a capitalist base of political and economic oppression with a superstructure of sexist literature and art. He finds reflections of socioeconomic injustices in which he fundamentally imitates modes of literature as a social reality.

\section{METHODOLOGY}

Our study demonstrated that the female leaders' influence has extended across time, culture, and profession. The study will also be highlighting the main ways in which women have influenced society and the world at large. Careers of the case leaders range from labourers, princesses, mothers, and activists. Data was collected from written literal works. These four plays explicitly showed the role and influence the woman gender has on the larger society. The main characters were women of a given position in society. Despite being wives and daughters to their husbands and fathers, respectively, they had the mandate to be fulfilled. Upbringing and formative years, family life, leadership career, and the role were key factors to be deeply studied.

The study focused on literal characters from Kilio cha Haki, Sudana, Pango, and Posa za Bikisiwa. Lanina is the woman leader who is the main character in the play Kilio cha Haki (Mazrui, 1981). Sudana is the main character of the female gender in the play Sudana (Mazrui \& Njogu, 2006). Katango is the female leader in the play Pango (Wamitila, 2003), while Bikisiwa is the main woman character in the play Posa za Bikisiwa (Mohamed \& King'ei, 2008). All these four leaders portrayed great influence in their society.

Prior to collecting data, the researcher sought a permit from the National Commission for Science Technology and Innovation (NACOSTI). The permit was of importance for being allowed entry to the various university libraries to review the literature relevant to our study. The permit allowed us to be identified as academic researchers wherever we went and are indicated to the issuing body that we are out in the field collecting data.

\section{FINDINGS}

\section{Literal Aspects, Woman as Main Character and Leadership Role}

This study focuses on a feminist and gender critique of culture. It generally found women leaders better educated, of high social standing, more ambitious than other women, having a similar profile like men, and highly placed in integrity standings. The upbringing of the chosen women leaders in the selected texts demonstrates common backgrounds and experiences amongst them. They are educated and wise. Their intellect levels are relatively higher than the other women in the text. Most of them received an education that put them on a different level than their fellow villagers. The life struggles in their various backgrounds and desire to lead and bring change to people's lives led them to push on and become worthy leaders. All the four leaders faced a number of common challenges like gender stereotypes, career preparation, family demands, sexual discrimination and a unique political office structure.

One of the challenges faced was family demands. Family demands like raising children for the married leaders like Lanina, mothered leader like Sudana, Katango for educated and still residing in her father's house and Bikisiwa who came from an affluent family for she was a princess. Family being a core unit in any society upholds togetherness and common family decisions. Children would delay one's entry to full-time leadership due to duties 
involved in homemaking. Husbands can also be a hindrance, a case is Mwengo who is Lanina's husband. He is dissatisfied and complains about her wife's role as the workers' leader.

The second challenge was career preparation. The chosen leaders were least prepared to take office. Several women leaders were homemakers and entered leadership offices after being forced by circumstances. But despite all these challenges, they entered these leader roles after being well educated. A good example is Katango, in the play, Pango who is seeking political office. She is educated and had just graduated as a trained teacher. Even this is not easy for no office is exclusive for women. She is abused by her competitor, a man Katango. She is also physically traumatised. She is unmarried, an issue that makes her competitor and her father advise her to get married before thinking of leading anyone. Despite all this, she finally succeeds to ascend the leadership ladder. The study helps show the experiences. She manages to woo youth like Kikubi and Mbabekazi to accept her as a change in society. A career would be a challenge and would largely influence when one is ready and seriously pursuing a leadership role.

The third challenge that influenced women's leadership was gender stereotypes. Culture played a great role and still has a big impact on women's leadership. Most women leaders experience negative stereotypes associated with being a woman. Women found that gender stereotypes came into play when men became leaders and were always encouraged to follow politics. A small percentage of the public was not willing to accept a woman leader. Society's perception of the maleness of high office raises questions about a female leader's toughness, ability to make difficult decisions, as commander-in-chief, and having any understanding in matters economics. A very large percentage, about eighty per cent of many African societies, believe a woman was as capable as a man on economic policy. About the same percentage above believed a woman was capable of matters of diplomacy and even able to lead the military. Male leadership was inexistent as long as humanity lives, and all religions embraced this. A difference was felt when a woman emerges, ascends and leads. Watson et al. (2005) being a devout Roman Catholic and a feminist and the world having a preconceived image is a dominant part of the experiences of women leaders. These researchers showed how a woman is emotionally attached to issues as compared to their male counterparts. Many African societies have shown the great damage of stereotypes on the role of a woman as a leader.

The other challenge for women leaders was sex discrimination. The woman's place was the kitchen rather than at home. All women around the world were classified as second-class citizens. They were allowed to speak after men have spoken. They held few positions of authority and the great inequality of condition and opportunity that is in society as shown in the selected plays.

Lanina in Kilio cha Haki is reminded by her husband and father that her place is home. She is scolded to have not been around to cook for her children. Many African traditional societies dictated the woman stay at home and carry out household chores. Any married woman was supposed to stay at home and take care of her husband and children. And any unmarried woman was told to get married fast when she was fully grown. A case is Katango in Pango and Bikisiwa in Posa za Bikisiwa. Sudana in Sudana who got children from rape was despised and faced harsh treatment by both society and even her own children like Sudzungu. Sudzungu tells her mother to allow her to play prostitution so that they can get favours from their kidnappers.

Positive traits that encompassed the main character included; one being brave. The degree of brevity was expressed by not fearing any act of physical or emotional trauma. This ability to lead was also told by the leader being able to tell the truth from a bunch of lies. Respect for all members of society despite age or gender was of great importance. Confident and free from any dogmas as well as being able to deduce right and wrong. Courageous and firm in decision-making was also a strong trait. One also got to be a good orator and fluent. Psychology also favours the female gender on language proficiency and excellence. Many good linguists have been women who have an agenda for their society. Intelligence was also key in any leader and this was well placed in the main characters. High ability of intellect from the brain, not the soul to do what is right and desirable and not rigid to change. Was flexible and accommodative towards the right 
direction. A point to note is that character shaped the individual in any given society. Politeness and kindness were traits seen as signs of weakness in the women leaders.

\section{CONCLUSION}

Women in leadership is a study that looks critically at how these leaders influence the other members of society. It deals with both traditional and conventional ideas. It deals with the feminist theory that analyses culture, power, the female and male authority that demand attention in the modern and postmodern world.

\section{Affirmative Action}

This is an action or policy favouring those who tend to suffer from discrimination, especially in relation to employment or education. Policy, in the layman's language, is the decree to steer development in a certain way. In this case, the decree is to have a society that includes the woman as a leader and nothing less. This can be said to be a move towards a positive discrimination policy favouring member of a disadvantaged group who suffer or have suffered discrimination within a culture to make a big difference from the permanent norms and beliefs of a given African society. Positive steps have been taken to increase the representation of women and minorities. The focus is on balanced politics to create diversity in both racial and social realms. It also focuses on expanding equality with no regard to creed nor gender. Efforts have been made to improve opportunities for historically excluded groups. The process to double or triple numbers are aimed at so that women and children can live better and compensate for centuries of social and economic oppression.

According to Sexual Politics in Millett's discourse, the dismissal of psychoanalysis focused exclusively on a theory of male chauvinism. The idea of cultural reorientation has been part of the feminist and gender issues. They have dealt widely with an opposition between males and females and have gone further to encompass views like rape and homosexuality. A feminist consideration tends to highlight the question of sexual difference, linguistic strategies, and cultural understanding in order to understand and analyse representations of women. Women's excess in all areas of production and practice, any excess must be brought under control according to patriarchal culture to keep business going as usual.

\section{RECOMMENDATIONS}

It is clear that women still face many challenges. In Africa, many movements were staged to express concern for women. A case was the Maputo Protocol which states clearly its mandate to brainwash Africans into radical feminist language and way of thinking. Proponents of this protocol aimed at full eradication of traditional African family cultures for a complete transformation into Western, Marxist-Style. It modified social and cultural patterns of conduct on both men and women through public education. Its view was achieving the elimination of harmful cultural and traditional practices based on inferiority and stereotyped roles on women.

Its main aim was to protect every woman's right and dignity from all forms of violence, both sexual and verbal. Arbitral restrictions were imposed on any form of deprivations of fundamental freedoms in the private and public life of women. It laid great emphasis on equal representation for women in careers as it is dictated in any social policy. This blueprint was to lay the foundation and implementation of eradicating all forms of discrimination against women through legislation or institutions of gender equality. It also supported initiatives that ensure women are protected as stipulated in international declarations and conventions. The movement also reaffirmed the principle of promoting gender equality as enshrined in the Constitution Act of the African Union. It recognises women as equals to men who should enjoy all human rights and fundamental freedoms in all spheres of life.

\section{Suggested Areas of Further Research}

Further study is needed to understand the experiences of women leaders from other continents. Research can be done on men characters who are leaders and critique their role and influence in the larger society. 


\section{REFERENCES}

Beauvoir, S. (1953). Second Sex. New York: Knopf.

Chauveau, M. (1997). Egypt in the Age of Cleopatra. Ithaca. Cornell University Press.

Jackson, G. (1998). Women who Ruled. A Biographic Encyclopedia. Barnes \& Noble Books.

Jackson, P. (1999). Understanding West Literal works. Dublin. Ireland Pub. Ltd.

Mazrui, A. \& Njogu K. (2006). Sudana, Nairobi: Longhorn Publishers Ltd.

Mazrui, A. (1981). Kilio cha Haki. Nairobi. Longhorn Publishers.

Millet, K. (1969), Sexual Politics. New York: Doubleday \&Co.

Mohamed, S. Na King'ei K. (2008) Posa za Bikisiwa. Nairobi: Longhorn Publishers Ltd.

Wamitila, K. W. (2003). Pango. Nairobi, Kenya: Focus Publishers. 